\title{
INFORMED CONSENT BETWEEN BIOETHICAL THEORY AND MEDICAL PRACTICE: A CALL FOR ACTIVE VULNERABILITY
}

\author{
UDC $349: 61$
}

\author{
Marija Selak \\ Faculty of Humanities and Social Sciences, University of Zagreb, Croatia
}

\begin{abstract}
The emancipation of bioethics from new medical ethics is a result of the awakening of the role and the rights of patients. Thus, the appearance and realization of informed consent can be seen as an example of the mode in which the contemporary attitude towards medical practice has developed, starting from paternalism and ending in recent attempts for the establishment of a dialogue. Nevertheless, a more detailed analysis of the informed consent practice, with emphasis on the situation in Croatia, shows that this progress is more theoretical, and less related to everyday procedures with patients encounters with physicians. In view of this, in his PhD thesis "Respecting Patients' Right to Information Regarding Medical Procedure during Hospital Treatment in Croatia" Luka Vučemilo shows that during their stay in hospitals patients do not fully realize their right to be informed. In this paper, we will emphasize the asymmetry in the physician's and the patient's perception of informed consent and its formal self-sufficiency. This will serve as confirmation of the fact that informing for the purpose of giving consent to particular medical treatment is not being implemented properly. In order to try to understand the problems concerning the realization of informed consent, in the conclusion of the paper, the same as in the beginning, in order to observe its appearance, we will once again attempt to extend our context and take into consideration the contemporary worldhistorical situation.
\end{abstract}

Key words: informed consent, bioethics, patient, physician, authority

Received May $17^{\text {th }}, 2016 /$ Accepted May 22 $2^{\text {th }}, 2017$

Corresponding author: Marija Selak

Faculty of Humanities and Social Sciences, University of Zagreb, Ivana Lučića 3, HR-10000 Zagreb, Croatia E-mail:marija.selak@gmail.com 


\section{INTRODUCTION. \\ BIOETHICS AND INFORMED CONSENT: THE STORY ABOUT THE SAME ORIGIN}

To answer the question why and how bioethics appeared, we should take a look at the wider social context. Even before the 1960s, when bioethics was officially "established", society already craved for a stronger engagement in the public health decision-making process. The protests against nuclear weaponry, and similar movements with emphasis on ecological issues, were present worldwide. Efforts on the "street" soon received an institutional framework. In Seattle, a "God Committee" (the Admissions and Policies Committee of the Seattle Artificial Kidney Center at Swedish Hospital) was created with the task of deciding who should have the advantage in hemodialysis treatment, since the capacity of the hospital was not large enough to provide treatment to all the patients who needed it. What was special about this Committee was that not only doctors decided about medical procedures. Moreover, they were a minority in the Committee (Zagorac, Jurić, 2008; Matulić, 2001: 25-36). Although it was they who performed and provided the treatment, when it came to the decision as to "who should live and who should die", their voice was no longer more important than the voice of the "representative of the public". Thus, the constitution of this committee can be seen as one of the first "official" confirmations of the limits of medical power. After "new medical ethics" was born, bioethics expanded its field of study and methodology to adjust to the demands of the modern world, preoccupied with the idea of techno-scientific progress. We can observe its extension from medical ethics, followed by principlism, to ethical pluralism and an interdisciplinary approach and, finally, to life as a whole, pluriperspective methodology and orientation of knowledge (Čović, 2011; Selak, 2013). Furthermore, the integrative bioethics methodological inclusion of non-scientific, religious and cultural perspectives has confirmed that a purely scientific approach can no longer provide an answer to the challenges we are facing. Correspondingly, the idea of progress was replaced, or expanded with new views based on the principle of responsibility, inaugurated by Hans Jonas and his famous imperative of responsibility (Jonas, 1984).

This emancipation of bioethics from new medical ethics to integrative bioethics was followed by the awakening of the role and rights of patients. Hence, we can take the appearance of informed consent as testimony of the line of development of the contemporary attitude towards medical practice, from earlier paternalism to new attempts towards the establishment of a dialogue. Although informed consent has a background in the legal practice, and the very term "informed consent" is related to the case Salgo v. Leland Stanford Jr. (1957) (Frković, 2006: 64-65), the verdict in this case was just procedural confirmation that medical practice is not valid if the patient is not properly informed. Additionally, in the 1960s and 1970s legal practice was supplemented with a moral component (Frković, 2006: 66 ), which was inevitable, since informed consent rests ultimately on a moral foundation (Young, 2004). As Ivan Šegota, one of Croatia's "fathers of bioethics", suggests informed consent is one of the most important acquisitions of bioethics, an "angular bioethical stone" that separates old from new medical ethics (Sorta Bilajac, 2010: 84).

The limits of medical power, which were confirmed through the "Seattle process", received a theoretical framework in the establishment of bioethics, and the demands of society for taking a greater role in the healthcare decision-making process gained legal support by making the guidelines about informed consent obligatory. Likewise, as integrative bioethics turned to non-scientific, religious and cultural perspectives, some authors similarly suggest that informed consent should be substituted with a choice which is 
ultimately based on “deep values” (Veatch, 2003: 530-531). Hence, John Stuart Mill's idea of liberty, which supposes that "each is the proper guardian of his own health, whether bodily, or mental and spiritual" (Mill, 2003: 516), finally received an opportunity to become a part of real practice. But was this opportunity really taken?

\section{THEORY IS ONE THING BUt PRACTICE IS ANOTHER: THE STORY ABOUT THE IMPLEMENTATION OF INFORMED CONSENT IN CROATIA}

Emphasis on dialogue instead of obedience to the instructions given (Gosić, 2005: 136) was intended to strengthen the relation between physician and patient by giving the patient the right and the possibility to (co)decide about the methods of his/her treatment and thus share the responsibility for the outcomes of medical procedures.

Nevertheless, although legally everything was in order and patients' rights were secured through the Patients' Rights Protection Act (1993; 1997; 2004), which included the right to be informed and (co)decide based on instructions provided by the Helsinki Declaration and the Universal Declaration on Bioethics and Human Rights, a more detailed analysis of the implementation of informed consent in Croatia shows that this progress was more theoretically established and not so much present in everyday encounters between physicians and patients (Babić-Bosanac, Borovečki, Fišter, 2008). ${ }^{2}$ Along these lines in his $\mathrm{PhD}$ thesis Respecting Patients' Right to Information Regarding the Medical Procedure during Hospital Treatment in Croatia Luka Vučemilo reveals how during treatments in hospitals patients do not fully achieve the right to be informed. Although we have adopted the necessary laws, patients are still not the central issue in the health-care system (Vučemilo, 2015: 7). Vučemilo points out the contradiction between the position of the patient, which is regulated by the law, and the real conditions he is facing. In order to see why this discrepancy is present, one must take a closer look at the problems that Vučemilo's queries have revealed.

\section{SELF-SUFFICIENCY OF THE INFORMED CONSENT PROCEDURE AS A PROBLEM OF A "COUNTRY IN TRANSITION”?}

Vučemilo's research has shown that $64 \%$ of patients comprehend the procedure of signing the informed consent form as a pure formality. Moreover, 54\% of patients do not fulfil this formality, since they have not expressed their consent in a written form. Furthermore, in $39 \%$ cases physicians have made a decision on their own, without consulting the patient, and half of the patients have stated that although they talked to their physician, they still did not feel they are taking part in the decision-making process. Vučemilo has also uncovered irregularities in the procedure of giving consent that show it is not really being implemented. In $39 \%$ cases nurses or hospital clerks were those who informed patients,

\footnotetext{
${ }^{2}$ Babić-Bosanac, Borovečki and Fišter (2008) suggest that for this discrepancy there are political and legal reasons on the one side and cultural and social reasons on the other. Political and legal reasons mean that the "capacity of the Croatian community for the implementation was not taken into account", there is also "the lack of political will to adopt subordinate implementation regulations to apply the existing legislation in practice" and "there is a lack of transparency in the work of the competent bodies who should ensure the implementation of the existing legislation". Cultural and social reasons mainly refer to the insufficient level of informedness and education about the concept of patients' rights of both, patients and health workers (Babić-Bosanac, Borovečki, Fišter, 2008: 42-43).
} 
instead of physicians, and in the same percentage of cases patients were informed in the presence of other patients, which is not in accordance with the prescribed procedure (Vučemilo, 2015: 29).

Vučemilo points out that only $3.8 \%$ of the forms contain all necessary elements and $19.2 \%$ contain five basic elements out of six. The greatest problem are written materials that are given to patients ${ }^{3}$ in hospital since a uniform form for all hospitals does not exist (Vučemilo, 2015: 47). ${ }^{4}$ How much can they differ in content may be seen if we compare two forms that are being used in Croatia for the procedure of General Anesthesia.

One is used at a private clinic: "After talking with an anesthesiologist, I am familiar with the anticipated anesthesia procedure and with the possibility of additional measures, if necessary (for example, a combination with other procedures / intubation anesthetics). I am aware of special risks and possible complications of the anesthesia procedure, of measures that follow and alternative interventions. I have no further questions. I feel informed enough and having had enough time to deliberate I agree on the scheduled anesthesia procedure."5

On the other hand, one of the public hospitals in Croatia offers a slightly different approach: "With my signature, I confirm that I am informed in detail about the benefits and the risks of the procedure, with other diagnostic and therapeutic possibilities, that I have understood the written material and that I was able to ask the physician questions which I needed in order to clarify the content. On appending my signature, I also confirm that I am aware and that I accept that, if during the high-risk procedure (operation or other invasive procedures) new unexpected moments appear, they may change the course of the procedure and the procedure may end differently than was explained earlier and that the reasons for this will be explained to me after the operation.",6

The differences may seem small but are crucial in bringing to light some of the problems the physician - patient relationship faces. First, the public hospital demands confirmation that the patient was able to talk to a physician: "I was able to ask the physician questions", while the private hospital presupposes that this has happened. This leads us to the assumption that the level of care and focus on the patient, probably due to infrastructural differences, is not the same in private and public hospitals. Also, the private hospital form concludes with emphasis on how the patient feels: "I feel informed enough and after having had enough time to think", and the public hospital ends with the question of responsibility for the consequences of unexpected medical procedures: "If new unexpected moments appear, they may change the course of the procedure and the procedure may end differently than was explained earlier and the reasons for this will be explained to me after the operation". Thus, this short comparative analysis exposes two tasks of the informed consent procedure: to inform the patient, on the one hand, and to share the responsibility, to secure physicians from law suits, on the other. Which of these comes first (or last as emphasized above) may indicate who is really in the center of the health-care system: the patient or the physician.

\footnotetext{
${ }^{3}$ Vučemilo's research (2015) has shown that one third of the patients does not even receive them.

${ }^{4}$ Vučemilo (2015) points out that the content of the printed form for informed consent is not regulated; it is left to each hospital to decide for itself, of course they need to receive approval from responsible institutions (chambers and agencies).

${ }_{5}^{5}$ Podobnik Maternity \& Gynecology Outpatient Clinic, Sveti Duh 112, Zagreb (https://www.podobnik.hr/wpcontent/uploads/anestezija-opca.pdf).

${ }^{6}$ Pula General Hospital, Zagrebačka 30, Pula (http://www.obpula.hr/wp-content/uploads/2015/05/op\%C4\%87aanestezija.pdf).
} 
Besides this rather subtle and interpretative difference, there are other more obvious problems with the informed consent form. One of them is that, paradoxically, the form serves more to inform those who are able to inform themselves, instead of informing those who do not have sufficient education to understand the procedure. Vučemilo thus shows that none of the forms are written at a primary school level (Vučemilo, 2015: 53). ${ }^{7}$

The level of education of patients and the perception of informed consent practice represents a very interesting question. The more educated the patients are, the more the relation with physicians is evaluated as being bad. If we take this result into consideration with the way forms are written, then this does not prove that medical vocabulary is after all inaccessible to the average inhabitant of Croatia, since they obviously give better grades to their relation with the physician, but it rather shows something else. While less educated patients do not know that they are not really informed, because they are inclined to think that their lack of comprehension is a matter of their poor education, highly educated patients are also educated about their rights. Hence, they are aware that they should understand and that, in spite of that, they are not receiving adequate information. This is what Sanja Babić-Bosanac, Ana Borovečki and Kristina Fišter refer to as cultural and social reasons for the problems for the implementation of informed consent and they warn about the insufficient level of informedness and education about the concept of patients' rights of both patients and health workers (Babić-Bosanac, Borovečki, Fišter, 2008: 42).

Aside from patients' lack of awareness about their rights, a further problem is that forms are not written clearly, which leads us to the conclusion that informed consent is a purely legal norm and, therefore, self-sufficient, meaning it is not written to be understood, but rather to fulfil a legal obligation. ${ }^{8}$

The final proof of the self-sufficiency of the informed consent procedure is the asymmetry in the perception of physicians and patients. In their research Jukić and associates, to which Vučemilo also refers in his dissertation, a significant difference in the perception of doctors and physicians has been revealed. 30, $7 \%$ of physicians declared that they have personally informed patients about their medical condition and forthcoming clinical procedures in detail, but only $11 \%$ of patients reported that they were informed in detail. Furthermore, $52.6 \%$ of physicians reported that their patients received sufficient information to be able to decide about their treatment, but only $11.7 \%$ of patients reported the same (Jukić, Kozina, Kardum, Hogg, Kvolik, 2011).

To summarize: Vučemilo's research, in the part that we have emphasized for the purpose of this paper, shows that giving consent in the case of most of the patients is only a formality. Furthermore, the lack of clarity in the forms enables the situation to remain as is and a review of two different forms for the procedure of general anesthesia suggests that it may be due to the fact that the patients are not really in the center of the healthcare system, thus the form is actually written for the sake of physicians and not patients. Also, there is a significant difference in what being informed means to physicians and to patients, where patients feel deprived in view of the amount of information that is given to them. This shows that there is a discrepancy between theory and practice, i.e. it suggests that there are oversights in the implementation of the idea of informed consent in Croatia.

\footnotetext{
${ }^{7}$ Vučemilo (2015) furthermore explains that informed consent forms are written in a complex way. More than $80 \%$ of the population over the age of 15 would not be able to understand them, bearing in mind the percentage of those who are highly educated.

${ }^{8}$ The results of the research of the informed consent in obstetrician done by Aleksandra Frković and Silvija Zec Sambol suggest the same (Frković, 2006: 92).
} 
Vučemilo claims that the question of consent of an informed patient is of high importance for countries in transition and Croatia is one of them. In these countries, the legal and the real position of the patient are not the same (Vučemilo, 2015: 49). This statement assumes that the practice of informing is worse in Croatia than in certain other countries and that Croatian practice is similar to the practice of certain other countries in transition. This proves that a thorough comparative analysis of informed consent practices in "transitive" countries and "other" countries is necessary. On the other hand, many authors point out problems of informed consent practice in "other" countries across Europe, especially when it comes to researches and clinical practice (Frković, 2006: 84). Similarly, in some countries, such as Japan, due to cultural differences, the idea itself faces specific problems since the relation between a physician and a patient is seen differently (Frković, 2006: 73). Additionally, a discussion about the limits of informed consent becomes one of the issues tackled in bioethics (Frković, 2006: 90). Moreover, Robert M. Veatch suggests that, as a transitional concept, it should be abandoned (Veatch, 2003).

If a significant number of countries have problems with the practice of informed consent, this may vary as a result of the level of their development or their cultural background, but yet do not disappear, and so we must ask ourselves why this is. In order to try to understand these obstacles in the realization of informed consent, in the conclusion of this paper, as we did in its beginning to observe its appearance, we will once again attempt to extend our context and take into consideration a contemporary world-historical situation.

\section{CONCLUSION. THE LACK OF AUTHORITY AND THE POSSIBILITY OF ACTIVE VULNERABILITY}

This, finally, rather philosophical investigation of the patient - physician relationship leads us to the question of the role of authority where a contemporary change of the center of authority, as Renaut (2015) defines it, suggests that the idea of informed consent is a result of democratic processes and thus cannot, as a consequence, escape from certain structural problems. It is precisely this loss of medical authority, as one of the manifestations of the realization of the idea of democracy as equality, which enables patients to enter the scene and their rights to appear within the medical landscape. In times which mark the end of authority, as Alain Renaut defines it, including the end of medical authority, the questions about the nature of the power and consequences of the destruction of its firm center are once again being posted.

Although the physician has lost his position of authority unexpectedly, he has been burdened with even more responsibility and the power that comes with it (Renaut, 2015). Renaut states that the authority of the contemporary physician is not based on his medical practice, but rather on his scientific achievements, which implies that it comes as a result of a degree gained in a medical school (Renaut, 2015: 196-201). As a scientist, one who operates in the field of techne in an Aristotelian sense, a physician is no longer perceived as "one that cures/repairs", but also as one who creates, who can change and control life (Renaut, 2015: 197). This may be observed if we take a look at what is being achieved today within the field of biotechnology, genetic modifications etc. (Renaut, 2015: 193). Secular society, "abandoned" by God, now believes in men with endless power (Löwith, 1949). The human being takes over the role of an absolute being. For a physician, this means he is no longer someone who needs to simply cure the disease, but someone who can 
bring happiness (Renaut, 2015: 203-206). This change can be perceived if we take a look at the modern definition of health. Health is now defined as "a state of complete physical, mental and social well-being and not merely the absence of disease or infirmity". 9

We live in a society that believes in perfection and, therefore, punishes imperfection, as can be seen in the rise of legal claims against doctors for malpractice. Nevertheless, the human factor cannot be eliminated. And this works both ways: the end of authority which enabled the questioning of the medical practice has revealed the scariest truth of all and that is that physicians, as those persons who need to offer information for consent, are also clueless when it comes to the question as to what is in the patient's best interest (Veatch, 2003: 526-529). Another structural problem when it comes to the realization of democratic equality, which is often emphasized in the informed consent debate, is the problem of the possibility of reception. Informed consent is never completely informed because our knowledge about medicine and the treatment that is necessary is not the same as the knowledge of the physician. Thus, informed consent is "no more than an elaborate ritual" (Ingelfinger, 1992: 357).

If we will never be equal in our competences and educated enough to fully understand the procedure, why do we go through the trouble of signing the forms and talking to physicians? This may be due to the fact that the form itself for informed consent is not a pure transmitter of information but actually serves another purpose. Firstly, it can be viewed as a reminder that nobody's power should be unlimited, which is really a consequence of democracy and the fulfillment of the idea of equality as Renaut sees it in The end of authority. Secondly, and accordingly, it shows that the place of authority is emptied, hence every consent can be only conditional. If you, as a physician, are not following the procedure, you may lose your job. Although I am the one lying in the bed while you are operating, it is not just you trying to fix me, it is also me testing you.

Finally, as a possible solution to the problems that arise from the end of (medical) authority, the form reminds us of the often-neglected communicative nature of medical practice. No matter how well we are able to understand the form, informed consent is essentially there to secure the surrounding of trust, to calm us down, to direct physicians and patients one to towards the other. Written or oral agreement is, or should be, just a confirmation that a safe environment has been created.

The need for making this trust visible and "official" appeared after World War II, where it was necessary to restore the reputation of physicians, due to the fact that some of them had abused their power. Although by becoming obligatory the procedure of informed consent enabled patients to feel (more) secure, not all of its side effects are positive. The process of standardization of human relations leads to quantification and thus reduction of trust. Although one can manipulate with blind trust, extraction of trust forms human relationships, the belief that it can be framed with a signature of some document, has a destructive background. One should bear in mind, as Vučemilo points out, that the fulfilment of the rights of the patients is also followed up in annual reports of the national program for the protection of consumers (Vučemilo, 2015: 7). What does that say about medical practice and life in general? Health has a price and everybody in the process of rehabilitation has their calculation. But trust cannot be quantified, turned

\footnotetext{
${ }^{9}$ Preamble to the Constitution of World Health Organisation (WHO) as adopted by the International Health Conference, New York, 19 June - 22 July 1946; signed on 22 July 1946 by the representatives of 61 States (Official Records of WHO, no. 2, p. 100) and entered into force on 7 April 1948.
} 
into goods, left to the market or taken away. Bio-politically speaking, in order to fight against manipulation with life, we must fight to preserve this qualitative component of human relations.

In this "signature verified" quantitative approach to medical practice, where physicians are also victims of a system, there is no time for them to establish a relation of trust with patients because it implies a deeper responsibility and the creation of an emotional relationship with a patient. Nobody will ask you how your patients feel, they will only check how many, technically speaking, successful operations you have completed. Therefore, our very last question is: In a contemporary world grounded on completely opposite values, is it even possible for both sides to recreate the surrounding of trust and thus to answer a call to open themselves, to be actively vulnerable? (Selak, 2017)

\section{REFERENCES}

Babić-Bosanac, S., Borovečki, A., Fišter, K. (2008). Patients' Rights in the Republic of Croatia - between the Law and Reality, Medicinski glasnik, Vol. 5, No. 1, 2008, pp. 37-43.

Čović, A. (2011). Pojmovna razgraničenja: moral, etika, medicinska etika, bioetika, integrativna bioetika (Conceptual Demarcations: Morals, Ethics, Medical Ethics, Bioethics, Integrative Bioethics). In Čović, A., Radonić, M. (eds.), Bioetika $i$ dijete. Moralne dileme u pedijatriji, Pergamena, Hrvatsko društvo za preventivnu i socijalnu pedijatriju, Zagreb, 2011, pp. 11-24.

Frković, A. (2006). Bioetika u kliničkoj praksi (Bioethics in Clinical Practice), Pergamena, Zagreb, 2006.

Gosić, N. (2005). Bioetika in vivo (Bioethics in vivo), Pergamena, Zagreb, 2005.

Ingelfinger, F. J. (1992). Informed (but Uneducated) Consent. In Munson, R. (ed.), Intervention and Reflection: Basic Issues in Medical Ethics, Wadsworth Publishing Company, Belmont, 1992, pp. 355-357.

Jonas, H. (1984). The Imperative of Responsibility, University of Chicago Press, Chicago.

Jukić, M., Kozina, S., Kardum, G., Hogg, R., Kvolik, S. (2011). Physicians Overestimate Patient's Knowledge of the Process of Informed Consent: A Cross-Sectional Study, Medicinski glasnik, Vol. 8, No. 1, 2011, pp. 39-45.

Löwith, K. (1949). Meaning in History: The Theological Implications of the Philosophy of History, The University of Chicago Press, Chicago.

Matulić, T. (2001). Bioetika (Bioethics), Glas Koncila, Zagreb.

Mill, J. S. (2003). On Liberty. In Kuhse, H., Singer, P. (eds.), Bioethics: An Anthology, Blackwell Publishing, Malden et al., 2003, pp. 515-516.

Renaut, A. (2015). Kraj autoriteta (The End of Authority), TIM press, Zagreb.

Selak, M. (2013). Ljudska priroda i nova epoha (Human Nature and New Epoch), Naklada Breza, Zagreb.

Selak, M. (2017). Ima li kraja (liječničkom) autoritetu? (Is /Physician's/ Authority Unlimited?), Liječničke novine, Vol. 17, No. 156, February 2017, p. 93.

Sorta Bilajac, I. (2010). Informirani pristanak u UNESCO-vim bioetičkim dokumentima (Informed Consent in UNESCO's Bioethical Documents), Jahr, Vol. 1, No. 1, 2010, pp. 86-94.

Veatch, R. M. (2003). Abandoning Informed Consent. In: Kuhse, H., Singer, P. (eds.), Bioethics: An Anthology, Blackwell Publishing, Malden et al., 2003, pp. 523-532.

Vučemilo, L. (2015). Uvažavanje prava bolesnika na obaviještenost o medicinskom postupku tijekom bolničkoga liječenja u Hrvatskoj (Respecting Patients' Right to Information regarding the Medical Procedure during Hospital Treatment in Croatia), PhD dissertation, Medical School, University of Zagreb.

Young, R. (2004). Informed Consent and Patient Autonomy. In Kuhse, H., Singer, P. (eds.), A Companion to Bioethics, Blackwell Publishing, Malden et al., 2004, pp. 441-451.

Zagorac, I., Jurić, H. (2008). Bioetika u Hrvatskoj (Bioethics in Croatia), Filozofska istraživanja, Vol. 28, No. 3,2008 , pp. $601-611$ 


\section{INFORMISANI PRISTANAK IZMEĐU BIOETIČKE TEORIJE I MEDICINSKE PRAKSE: POZIV NA AKTIVNU RANJIVOST}

Emancipacija bioetike od nove medicinske etike je rezultat buđenja uloge i prava pacijenata. $U$ tom smislu, pojavu i realizaciju informisanog pristanka može da se uzme kao primer razvojne linije savremenog odnosa prema lekarskom delovanju, od ranijeg paternalizma prema novijim pokušajima da se uspostavi dijalogičnost. No, podrobnija analiza prakse informisanog pristanka, sa naglaskom na situaciji u Hrvatskoj, ukazuje na to da je više reč o teorijskom napretku, a manje o stvarnom svakodnevnom postupanju u susretu lekara i pacijenata. Na tom tragu, Luka Vučemilo u svojoj doktorskoj disertaciji pod nazivom „,Uvažavanje prava bolesnika na obaveštenost o medicinskom postupku tokom bolničkog lečenja u Hrvatskoj “ dokazuje da pacijenti tokom boravka u bolnicama ne ostvaruju u potpunosti pravo na obaveštenost. Zato u ovom radu stavljamo naglasak na asimetriju $u$ percepciji informisanog pristanka kod lekara i pacijenata, kao i na njegovu formalnu samodovoljnost. Navedeno služi kao potvrda da se informisanje u svrhu pristajanja zaista ne provodi ispravno. Da bismo razumeli probleme koji se pojavljuju u realizaciji informisanog pristanka, u zaključku ovog rada, kao i uvodu, gde smo analizirali njegovu pojavu, pokušavamo da proširimo naš kontekst $i$ da uzmemo u obzir savremenu svetsko-istorijsku situaciju.

Ključne reči: informisani pristanak, bioetika, pacijent, lekar, autoritet 